\title{
Stem cell characteristics of dormant cells and cisplatin-induced effects on the stemness of epithelial ovarian cancer cells
}

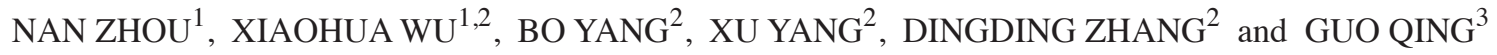 \\ ${ }^{1}$ Department of Obstetrics and Gynecology, Hebei Medical University, Shijiazhuang, Hebei 050017; \\ ${ }^{2}$ Department of Obstetrics and Gynecology, Bethune International Peace Hospital, Shijiazhuang, Hebei 050082; \\ ${ }^{3}$ Department of Obstetrics and Gynecology, First Hospital of Shijiazhuang, Shijiazhuang, Hebei 050011, P.R. China
}

Received November 30, 2013; Accepted July 1, 2014

DOI: $10.3892 / \mathrm{mmr} .2014 .2483$

\begin{abstract}
Tumor dormancy is a common biological property of malignancies and a leading factor in treatment failure, metastasis and tumor recurrence. The present study generated mouse xenograft models by injection of PKH26-labeled SKOV3 ovarian cancer cells, which were divided into two groups: The control group (SKOV3-P tumors,) and the treatment group that generated resistant tumors following prolonged administration of cisplatin (SKOV3-R tumors). Administration of cisplatin resulted in inhibition of the tumor growth and SKOV3-R tumors coexisted with their host at a stable size. According to fluorochrome PKH26 retention, there were multiple cell clones (PKH26 $6^{\text {hi }}$ PKH26 $6^{\text {low }}$ and $\mathrm{PKH} 26^{\text {neg }}$ cells) in the single cell line generated from xenograft tumors. PKH26 ${ }^{\text {hi }}$ subsets in SKOV3-P and SKOV3-R tumors were dormant cells, as the majority were arrested in $\mathrm{G}_{0} / \mathrm{G}_{1}$ phase and expressed high levels of the stem cell markers Oct-4, Nestin, CD117 and CD44. PKH26 ${ }^{\text {hi }}$ subsets also demonstrated greater clonogenic capability in vitro and tumorigenicity in vivo, as compared with $\mathrm{PKH} 26^{\text {low }}$ and $\mathrm{PKH} 26^{\text {neg }}$ cells. Notably, chemotherapy was demonstrated to lead to the enrichment and enhanced stem-like characteristics of dormant/slow-cycling PKH26 ${ }^{\text {hi }}$ cells. The results of the present study have demonstrated for the first time, to the best of our knowledge, that dormant tumor cells exhibit stem-like characteristics, and that cisplatin enhances these characteristics in epithelial ovarian cancer cells.
\end{abstract}

\section{Introduction}

Epithelial ovarian cancer (EOC) is one of the most common forms of ovarian cancer, and the overall 5-year survival rate has

Correspondence to: Professor Xiaohua Wu, Department of Obstetrics and Gynecology, Hebei Medical University, Zhongshan 361 East Road, Shijiazhuang, Hebei 050017, P.R. China

E-mail: xiaohuawu65@yahoo.com

Key words: epithelial ovarian cancer, $\mathrm{PKH} 26$, tumor dormancy, cancer stem cell, chemotherapy been reported as $15-30 \%(1,2)$. Patients with EOC commonly exhibit a satisfactory initial clinical response to optimal cytoreductive surgery followed by systemic paclitaxel- and platinum-based chemotherapy (3); however the majority of patients develop recurrences, with latency periods that range from years to decades. This time period (4) can be explained by tumor dormancy, which represents a subclinical equilibrium between the host's immune system and quiescent residual tumor cells, and also represents the minimal residual disease, a stage that remains a major obstacle in achieving complete remission. Tumor dormancy, associated with cancer stem cells (CSCs), has been previously extensively studied (5). Although it is unclear whether CSCs harbor the genetic alterations that are causative of cancer, primeval traits of adult stem cells may potentially explain tumor cell dormancy, such as their quiescence within a niche that is critical in tissue proliferation and protection of tissue homeostasis (6). It has therefore been hypothesized (7-11) that disease relapse is the consequence of CSCs, and following a period of quiescence, they subsequently resume growth.

The current isolation and identification methods of CSCs are based on their functional and phenotypic properties. CSCs are defined as a small population of undifferentiated cells and are responsible for tumor initiation, metastasis and recurrence following therapy (12). EOC originates from the normal ovarian surface epithelium (OSE) (13); however, the isolation and identification of stem cells in the OSE has yet to be achieved. Therefore, markers of CSCs associated with normal stem cells remain unknown for EOC. Therefore, markers of CSCs associated with normal stem cells remain unknown for EOC. In a previous study of EOC (14), screening and evaluation of other stem cell markers was applied to isolate the stem cell clones from ovarian tumors. It has been demonstrated that Nestin and Oct3/4 are expressed in ovarian CSCs and are associated with an immature stem-like and dormant cell population. In a previous study of EOC (13), it has been demonstrated that Nestin and Oct3/4 are the markers for ovarian CSCs and are associated with an immature stem-like and dormant cell population. Nestin is an intermediate filament protein that is a neuronal stem/progenitor cell marker that is expressed during the development of the central nervous system (15). Nestin has been associated with aggressive growth, metastasis and poor prognosis in certain types of 
tumor and is highly expressed in diverse types of cancer cell and proliferating tumor vasculature (16). Oct3/4, a member of the POU transcription factor family, is a marker of embryonic stem cells, and is expressed in embryonic stem cells, germline stem cells and undifferentiated embryonal carcinoma, whilst it is not expressed in differentiated cells $(17,18)$. The stem cell factor CD117 belongs to the tyrosine kinase receptor family with five immunoglobulin-like extracellular domains (19-22). CD117 serves an essential function in maintaining embryonic stem cells in an undifferentiated state, and is involved in the self-renewal of progenitor cells (23). The hyaluronic acid receptor CD44 antigen is expressed in numerous types of tumor and is also a marker for CSC subsets from several types of solid tumor (24).

Long-term label retention is extensively used for the identification of quiescent stem cells $(25,26)$; in particular, the fluorescent dye PKH26, which can irreversibly bind to the lipid bilayer of cell membranes and produce a stable, clear and precise fluorescent signal. Subsequent to each cell division, the label is equally partitioned among daughter cells. Furthermore, the PKH26 fluorescent dye has a low cytotoxicity and is not passed between dyed and undyed cells.

In the present study, mouse xenograft models were developed and the expression of stem cell markers (stemness) and tumorigenicity of label-retaining $\mathrm{PKH} 26^{\text {hi }}$ cells (dormant/slow-cycling ovarian cancer cells) was analyzed. Additionally, tumor growth and side effects were monitored following chemotherapy on xenograft tumors generated in mice by injection of ovarian cancer cells. When the growth of the mouse xenograft tumors ceased in the presence of chemotherapy, and were stable in size, the stem-like characteristics of the dormant/slow-cycling PKH26 ${ }^{\text {hi }}$ cells were analyzed.

\section{Materials and methods}

Cell line, cell culture and PKH26 labeling of cells. The SKOV3 ovarian cancer cell line (American Type Culture Collection, Manassas, VA, USA) was maintained in McCoy's medium (Sigma-Aldrich, St. Louis, MO, USA) supplemented with $10 \%$ fetal bovine serum. The cells were incubated at $37^{\circ} \mathrm{C}$ in a humidified atmosphere containing $5 \% \mathrm{CO}_{2}$. PKH26 labeling was performed according to the manufacturer's instructions (Sigma-Aldrich).

Animal housing, generation of tumors and cisplatin treatment. Female nude mice were bred and maintained at the Experimental Animal Center, Bethune International Peace Hospital (Shijiazhuang, China). All procedures were performed in accordance with the National Institute of Health Guide for Care and Use of Laboratory Animals (NIH publication no. 80-23). The current study was approved by the Animal Ethics Committee of Bethune International Peace Hospital (Shijiazhuang, China). The mice were maintained under sterile airflow conditions throughout the experiments. In order to induce subcutaneous (s.c.) tumor formation, PKH26-labeled SKOV3 cells $\left(1 \times 10^{7}\right)$ were suspended in $0.5 \mathrm{ml}$ phosphate-buffered saline (PBS) and injected subcutaneously into the left thigh of each mouse (5-6 weeks old, $18-20 \mathrm{~g})$. Approximately 14 days following the injection (average tumor volume, $100 \mathrm{~mm}^{3}$ ), the mice were randomly separated into two groups ( $n=35$ per group) as follows: The control group (SKOV3-P xenograft tumors) and the cisplatin treatment group (SKOV3-R xenograft tumors; intraperitoneal injection of $4 \mathrm{mg} / \mathrm{kg}$ cisplatin twice a week for 3 weeks). The experiments were terminated if the tumor size of the control group reached $1,500 \mathrm{~mm}^{3}$, or if the tumors of the treatment group coexisted with their host at a stable size subsequent to the end of the treatment for $\geq 1$ week. All surgical procedures were performed under sodium pentobarbital anesthesia, and all efforts were made to minimize the suffering of the animals. At the end of the experiment, the mice were sacrificed and the tumors were excised for PKH26-based sorting by flow cytometry.

Tumor growth and side effects. The mice were closely monitored every day and the body weights and tumor volumes were measured every 6 days. The tumor volume (TV) was evaluated using the following formula: TV $\left(\mathrm{mm}^{3}\right)=\left(\right.$ width $^{2} \mathrm{x}$ length $) / 2$. Blood samples were collected from the caudal vein once a week to count white blood cells (WBCs). All of the observed side effects of the chemotherapy were recorded during the experimental period, including weight loss, changes in behavior and feeding, reaction to stimulation and ruffing of fur. The grading criteria of the side effects were as follows: 0 ; WBC $\geq 6 \times 10^{9} / 1$, weight loss $\leq 5 \%$, no skin discoloration or drowsiness and a diet decline $\leq 25 \%$. I; WBC 5-6×10\% $/ 1$, weight loss $\leq 10 \%$, mild skin discoloration, short-term drowsiness and diet decline $\leq 50 \%$. II; WBC $\leq 5 \times 10^{9} / 1$, weight loss $\geq 10 \%$, severe skin discoloration, long-term drowsiness or coma and diet decline $\geq 50 \%$ ). Therefore, grade 0 indicated mild, I indicated moderate and II indicated severe side effects.

Tumor digestion for PKH26-based sorting and analysis by flow cytometry. The dissected tumors were finely minced and subjected to collagenase digestion $(10 \mathrm{mg} / \mathrm{ml}$ collagenase IV in McCoy's medium) to obtain single-cell suspensions. PKH26-labeled tumors yielded a continuous gradient of cells with fluorochrome $\mathrm{PKH} 26$ retention ranging from high (PKH26 ${ }^{\text {hi }}$, equivalent to pre-injected cells), low (PKH26 ${ }^{\text {low }}$, fluorescence intensity lower than pre-injected level), to total label quenching (PKH26 ${ }^{\text {neg }}$ cells). $\mathrm{PKH} 26^{\text {hi }}, \mathrm{PKH}^{2} 6^{\text {low }}$ and $\mathrm{PKH} 26^{\text {neg }}$ cells were identified, gated and sorted based on the fluorescence intensity of this continuous gradient for subsequent experiments. PKH26-based sorting was performed on a BD FACSAria Cell Sorter (BD Biosciences, Franklin Lakes, NJ, USA) and data were analyzed with BD FACSDiva software (BD Biosciences).

Cell cycle analysis. The freshly sorted PKH26 ${ }^{\text {hi }}, \mathrm{PKH} 26^{\text {low }}$ and $\mathrm{PKH}_{2} 6^{\text {neg }}$ cells from SKOV3-P and SKOV3-R tumors were plated in 60-mm dishes. Following 72-h culture, the supernatant was gently removed, to avoid detachment of the poorly adherent cells. The cells were detached by digestion with Trypsin-EDTA (Gibco-BRL, Carlsbad, CA, USA), pelleted by centrifugation at $1,700 \mathrm{x} \mathrm{g}$ for $4 \mathrm{~min}$, and washed twice with ice-cold PBS. A total of $1 \times 10^{6}$ cells were resuspended in $5 \mu \mathrm{g} / \mathrm{ml}$ DAPI buffer (100 mM Tris, $\mathrm{pH} 7.4$, $150 \mathrm{mM} \mathrm{NaCl}, 1 \mathrm{mM} \mathrm{CaCl}, 0.5 \mathrm{mM} \mathrm{MgCl}, 0.1 \%$ Nonidet P-40; Invitrogen Life Technologies, Carlsbad, CA, USA) and incubated in the dark for $30 \mathrm{~min}$ at room temperature. The 
DNA content was analyzed by flow cytometry using a cell sorter, and the proportion of cells in a particular phase of the cell cycle was determined with ModFit LT software for Windows version 3.2 (Verity Software House, Inc., Topsham, ME, USA).

Quantitative polymerase chain reaction ( $q P C R)$ analysis. qPCR analysis was used to measure the expression levels of the stem cell markers Nestin, Oct3/4, CD117 and CD44 in the three groups of PKH26 cells $\left(\sim 1 \times 10^{6}\right.$ cells from each group were harvested for PCR) from SKOV3-P and SKOV3-R tumors. The total RNA was isolated using TRIzol ${ }^{\mathrm{TM}}$ reagent (Invitrogen Life Technologies) and the cDNA was synthesized by reverse transcription according to the manufacturer's instructions of an RT-kit (BioTeke Corporation, Beijing, China). The qPCR was conducted using SYBR-Green (Beijing TransGen Biotech Co., Ltd., Beijing, China) with a Rotor Gene 6000 Real-time PCR Detection system (Biolabo Scientific Instruments SA, Châtel-St-Denis, Switzerland) according to the manufacturer's instructions. The reactions were performed in a $25 \mu 1$ volume. All qPCR was performed with the following cycling conditions: Initial denaturation at $95^{\circ} \mathrm{C}$ for $5 \mathrm{~min}$, followed by 40 cycles at $95^{\circ} \mathrm{C}$ for $30 \mathrm{sec}, 60^{\circ} \mathrm{C}$ for $30 \mathrm{sec}$ and $72^{\circ} \mathrm{C}$ for $3 \mathrm{~min}$. The results were analyzed by the $2^{-\Delta \Delta \mathrm{C}}$ method based on the cycle threshold $(\mathrm{Ct})$ values using GAPDH as an internal control.

The primers used for the qPCR were as follows: Nestin forward, 5'-AGC GTT GGA ACA GAG GTT GGA and reverse, 5'-TGT TTC CTC CCA CCC TGT GTC T, Oct3/4 forward, 5'-CAA TTT GCC AAG CTC CTG AAG and reverse, 5'-AGG GCC GCA GCT TAC ACA TG, CD117 forward, 5'-CAA GGA AGG TTT CCG AAT GC and reverse, 5'-CCC AGC AGG TCT TCA TGA TGT, CD44 forward, 5'-GAC ACA TAT TGT TTC AAT GCT TCA GC and reverse, 5'-GAT GCC AAG ATG ATC AGC CAT TCT GGA AT, GAPDH forward, 5'-ATT TGC AGG GGG GAG CCA; and reverse, 5'-CAT GAG TCC TTC CAC GAT ACC AAA. The experiments were repeated a minimum of three times.

Detection of protein expression by flow cytometry. Flow cytometric analysis was used to detect the protein expression of the stem cell markers Nestin (vol. per test, $5 \mu \mathrm{l}$ ); Oct3/4 (vol. per test, $20 \mu \mathrm{l}$ ); CD117 (vol. per test, $5 \mu \mathrm{l}$ ); CD44 (vol. per test, $20 \mu \mathrm{l}$ ) in the three groups of PKH26 cells from the SKOV3-P and SKOV3-R tumors. PKH26 ${ }^{\text {hi }}, \mathrm{PKH}_{2} 6^{\text {low }}$ and PKH26 ${ }^{\text {neg }}$ cells were sorted from SKOV3-P and SKOV3-R tumors, pelleted by centrifugation at $1,700 \mathrm{x} \mathrm{g}$ for $4 \mathrm{~min}$, and washed twice with ice-cold PBS. The PKH26 ${ }^{\text {hi }}, \mathrm{PKH}_{2} 6^{\text {low }}$ and PKH26 $6^{\text {neg }}$ cells $\left(\sim 1 \times 10^{6}\right)$ from the SKOV3-P and SKOV3-R tumors were resuspended in $100 \mu$ lice-cold PBS, stained with Nestin, Oct3/4, CD117 and CD44 mouse monoclonal fluorescein isothiocyanate-conjugated antibodies (BD Biosciences) and incubated in the dark for $30 \mathrm{~min}$ at room temperature. The stained cells were analyzed using an FACSAria flow cytometer. The mean fluorescence intensity represented the protein expression levels of the stem cell markers. The protein expression was evaluated using the following formula: Protein expression $=\lg \mathrm{X}$-Mode $\mathrm{x} 340$. The experiments were repeated a minimum of three times.
Clonogenicity assays. Clonogenicity assays were performed to determine the initiating tumor capacity of the three fractions of PKH26-retaining cells $\left(\mathrm{PKH} 26^{\mathrm{hi}}, \mathrm{PKH} 26^{\text {low }}\right.$ and PKH26 ${ }^{\text {neg }}$ ) from the SKOV3-P and SKOV3-R tumors. PKH26 ${ }^{\text {hi }}$, PKH26 $^{\text {low }}$ and $\mathrm{PKH} 26^{\text {neg }}$ cells were freshly sorted, counted and plated in triplicate at a density of 500 cells/well in 24-well plates. Once the majority of cell clones had expanded to $>30$ cells, they were washed twice with PBS, fixed in ice-cold methanol for $15 \mathrm{~min}$ and stained with Giemsa (Applichem GmbH, Darmstadt, Germany) for $15 \mathrm{~min}$ at room temperature. Subsequent to washing out the dye with distilled water, the clone numbers were counted. Colony formation efficiency was calculated as follows: Colony formation efficiency $=$ colonies/input cells $\times 100$. The clone formation assays were performed in triplicate.

Tumorigenicity assays. All the animal studies adhered to the protocols approved by the Animal Care and Use Committee of the Bethune International Peace Hospital (Shijiazhuang, China).

In the pre-experiment, $\mathrm{PKH} 26^{\mathrm{hi}}, \mathrm{PKH} 26^{\text {low }}$ and $\mathrm{PKH} 26^{\text {neg }}$ cells from SKOV3-P tumors were resuspended in $0.5 \mathrm{ml}$ PBS and were administered by s.c. injection into the six groups of nude mice at different cell densities $(5,000,10,000,20,000$, $40,000,80,000$ and $1 \times 10^{6}$ cells $\left./ \mathrm{ml}\right)$. The results indicated that the minimal cell densities for tumor initiation in the PKH26 $6^{\text {hi }}$ and PKH26 $6^{\text {low }}$ cells were 10,000 and 40,000 cells $/ \mathrm{ml}$, respectively, whereas $\mathrm{PKH} 26^{\text {neg }}$ cells failed to display tumor-initiating capacity at any of the tested cell densities. In the present study, two relatively small cell densities were selected in order to compare the tumorigenicity between SKOV3-P and SKOV3-R tumor-derived PKH26 cells.

PKH26 ${ }^{\text {hi }}, \mathrm{PKH}_{2} 6^{\text {low }}$ and $\mathrm{PKH} 26^{\text {neg }}$ cells derived from SKOV3-P and SKOV3-R tumors were respectively resuspended in $0.5 \mathrm{ml} \mathrm{PBS}$, and administered via s.c. injection into the four groups of 5-6-week-old female nude mice at either 10,000 or 20,000 cells $/ \mathrm{ml}$. The 10,000 cells $/ \mathrm{ml}$ SKOV3-P tumor group ( $\mathrm{n}=18$, three groups of six each) was injected with

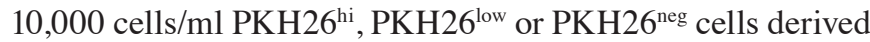
from the SKOV3-P tumors. The 20,000 cells/ml SKOV3-P tumor group ( $n=18$, three groups of six each) was injected with 20,000 cells $/ \mathrm{ml} \mathrm{PKH}_{2} 6^{\text {hi }}, \mathrm{PKH} 26^{\text {low }}$ and $\mathrm{PKH} 26^{\text {neg }}$ cells derived from the SKOV3-P tumors. The 10,000 cells/ml SKOV3-R tumor group ( $\mathrm{n}=18$, three groups of six each) was injected with 10,000 cells $/ \mathrm{ml} \mathrm{PKH}^{2} 6^{\text {hi }}, \mathrm{PKH} 26^{\text {low }}$ and PKH26 ${ }^{\text {neg }}$ cells derived from the SKOV3-R tumors. The 20,000 cells/ml SKOV3-R tumor group ( $\mathrm{n}=18$, three groups of six each) was injected

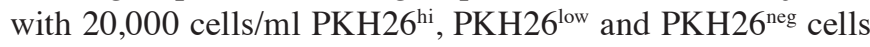
derived from SKOV3-R tumors. The engrafted mice were inspected every other day for tumor development by visual observation and palpation. The tumor formation was evaluated in the four groups of mice, 4 weeks subsequent to transplantation. The present study defined tumor formation as a xenograft tumor volume $\geq 100 \mathrm{~mm}^{3}$.

Statistical analysis. Values are expressed as the mean \pm standard deviation. The Student's t-test, $\chi^{2}$ test, exact probabilities in a $2 \times 2$ table and one-way analysis of variance was performed for the statistical evaluation of the data. The data were analyzed using SPSS statistical software (version 17.0 for Windows; 
A

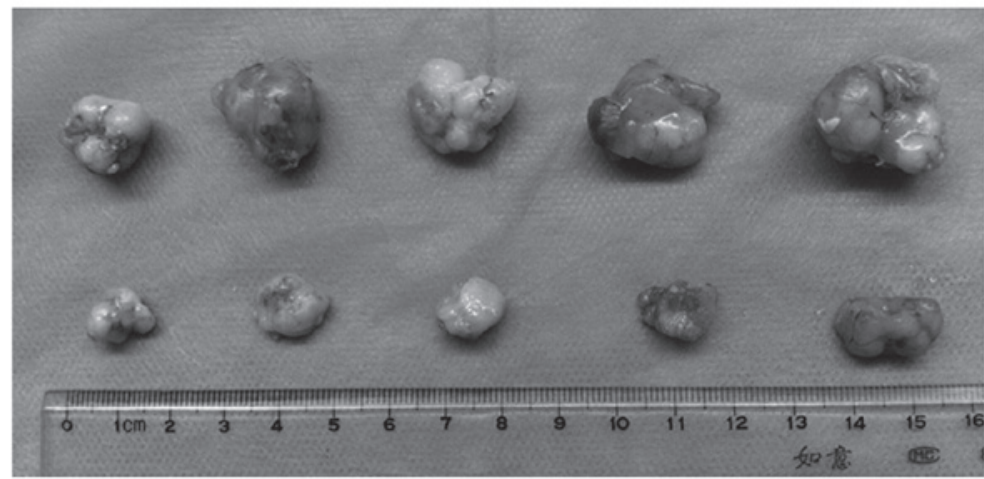

B

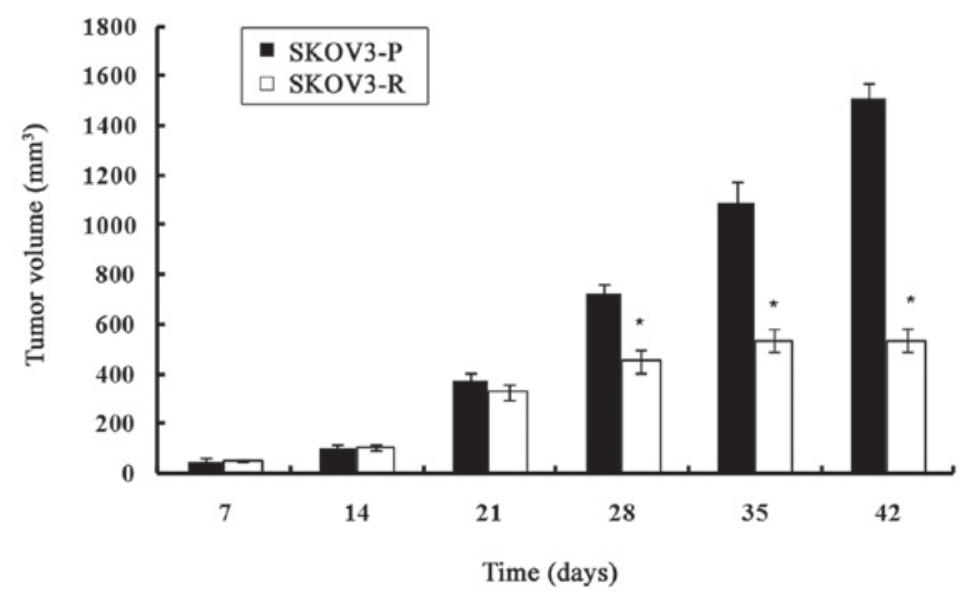

Figure 1. (A) Representative photographs of the xenograft tumors. (B) Tumor-growth of the two groups. SKOV3 xenograft tumors were established in nude mice. Two weeks later the tumor were established, when the size of the tumors had reached $100 \mathrm{~mm}^{3}$, the mice were randomized into two groups: Control and treatment groups. The mice receiving cisplatin treatment exhibited longer and more notable tumor growth delay. The data are expressed as the mean \pm standard error. Student's t-test was used to analyze the significance of the results. " $\mathrm{P}<0.05$ vs. the SKOV3-P tumor group. SKOV3-P, xenograft control tumors; SKOV3-R xenograft cisplatin treated tumors.

SPSS, Inc., Chicago, IL, USA). A P $<0.05$ was considered to indicate a statistically significant difference.

\section{Results}

Tumor growth and mouse condition assessment. For tumor formation, $1 \times 10^{7} \mathrm{PKH} 26$-labeled SKOV3 cells were administered by s.c. injection into the thighs of mice $(n=70)$. The engrafted mice (average tumor volume $100 \mathrm{~mm}^{3}$ ) were randomly assigned into two groups, 14 days following injection: The control $(n=35)$ and treatment $(n=35)$ groups. There were no significant differences in the xenograft tumor volumes between the two groups $\left(102.9 \pm 16.69 \mathrm{~mm}^{3}\right.$ vs. $\left.104.7 \pm 13.43 \mathrm{~mm}^{3}, \mathrm{P}=0.793\right)$ prior to treatment.

As indicated in Fig. 1, on day 35 (upon completion of cisplatin treatment), all the mice of the control group had larger xenograft tumors. The engrafted mice treated with cisplatin exhibited a significantly reduced tumor volume, as compared with the control group $\left(1089.95 \pm 82.37 \mathrm{~mm}^{3}\right.$ vs. $\left.535.7 \pm 44.69 \mathrm{~mm}^{3}, \mathrm{P}<0.05\right)$. An assessment of the growth rate revealed no significant difference from day 14 to 21 , but growth rate of the cisplatin-treated tumors, from day 21 to 28 , was significantly lower than the control group $\left(17.82 \pm 3.24 \mathrm{~mm}^{3} /\right.$ day vs. $50.14 \pm 2.92 \mathrm{~mm}^{3} / \mathrm{day}, \mathrm{P}<0.05$ ). From day 28 to 35 , the growth rate of the treated tumors was further reduced as compared with the untreated tumors $\left(11.72 \pm 3.52 \mathrm{~mm}^{3} / \mathrm{day}\right.$ vs. $51.67 \pm 15.59 \mathrm{~mm}^{3} /$ day, $\left.\mathrm{P}<0.05\right)$. One week after the end of the treatment (day 42), the mean tumor volume in the treatment group had not significantly increased, as compared with the tumor volume on day 35 ( $\mathrm{P}>0.05)$; however, there was a significant difference between the control and the treatment group $\left(1511.76 \pm 61.53 \mathrm{~mm}^{3}\right.$ vs. $\left.535.03 \pm 47.29 \mathrm{~mm}^{3}, \mathrm{P}<0.05\right)$. The two groups of mice reached the breeding termination standard on day 42 , and the mice were sacrificed by cervical dislocation under sodium pentobarbital anesthesia. Following sacrifice of the mice and dissection of the tumors, a significant difference in the weight of the tumors was observed between the two groups $(4.72 \pm 0.46 \mathrm{~g}$, SKOV3-P tumors vs. $1.03 \pm 0.11 \mathrm{~g}$, SKOV3-R tumors, $\mathrm{P}<0.05$ ).

At the end of cisplatin treatment (day 35), the mice treated with cisplatin exhibited various side effects, including weight loss $(21.41 \pm 0.74 \mathrm{~g}$, control group vs. $19.32 \pm 0.67 \mathrm{~g}$, cisplatin group, $\mathrm{P}<0.05)$, short-term drowsiness, mild skin discoloration, diet decline $(3.63 \pm 0.22 \mathrm{~g} /$ day, control group vs. $1.96 \pm 0.15 \mathrm{~g} / \mathrm{day}$, cisplatin group, $\mathrm{P}<0.05$ ) and leucopenia $\left(7.41 \pm 0.15 \times 10^{9} / 1\right.$, control group vs. $6.86 \pm 0.31 \times 10^{9} / 1$, cisplatin group, $\mathrm{P}<0.05)$. Although the chemotherapy treatment was causative of some of these side effects, the mice developed an extent of tolerance to the chemotherapy, based on the grading criteria of the side effects. 
A
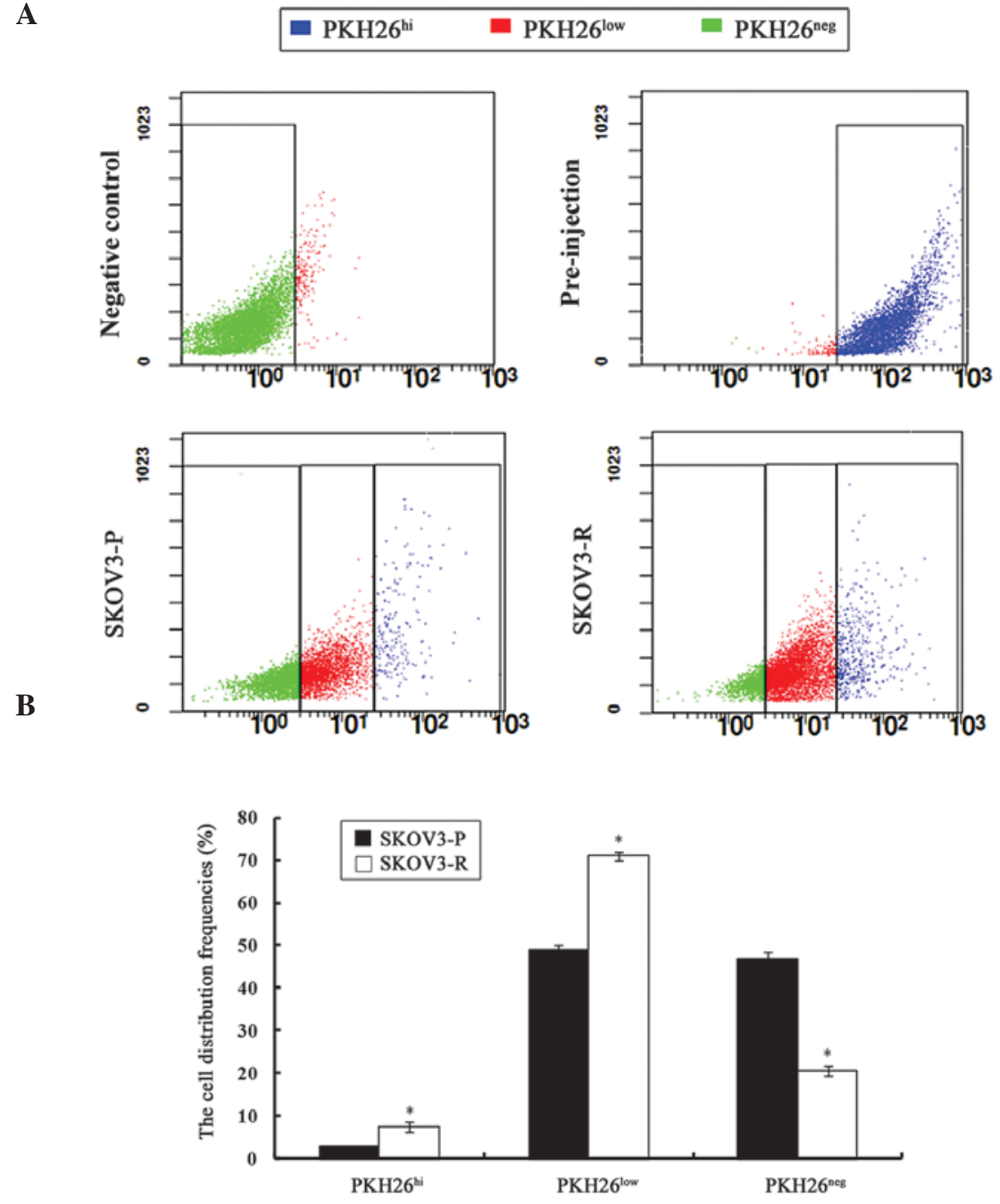

Figure 2. Identification of PKH26 label-retaining capacities within the tumors. Experimental design for in vivo-based PKH26 labeling to detect dormant/slow-cycling cells within tumors. (A) Representative PKH26 intensity profiles of pre-injected cells, SKOV3-P and SKOV3-R tumors. (B) The distribution of each fraction of cells between SKOV3-P and SKOV3-R tumors. The data are expressed as the means \pm standard error of three independent experiments. Student's $\mathrm{t}$-test was used to analyze the significance of the results. "P $<0.05$ vs. SKOV3-P tumor group. PKH26 $6^{\text {hi }}$, high PKH26 retention, equivalent to pre-injected cells; PKH26 ${ }^{\text {low }}$, fluorescence intensity lower than pre-injected level; PKH26 ${ }^{\text {neg }}$, total label quenching; SKOV3-P, xenograft control tumors; SKOV3-R xenograft cisplatin treated tumors.

Dormant and quiescent PKH26 ${ }^{\text {hi }}$ cells exist in xenograft tumors, which are enriched following cisplatin treatment. Analysis of SKOV3-P tumors for the distribution of PKH26 intensity revealed a continuous gradient of cells, with PKH26 retention ranging from $\mathrm{PKH} 26^{\text {hi }}$, to $\mathrm{PKH} 26^{\text {low }}$, to $\mathrm{PKH} 26^{\text {neg }}$. The presence of PKH26 ${ }^{\text {hi }}$ cells suggested a dormant or slow-cycling state, $\mathrm{PKH} 26^{\text {low }}$ cells indicated a partial label dilution representative of limited division, and presence of PKH26 ${ }^{\text {neg }}$ cells implied a rapid division. Such profiles were also identified in SKOV3-R tumors (Fig. 2A).

The percentage of each PKH26 retention fraction varied between SKOV3-P and SKOV3-R tumors (Fig. 2B). The percentage of sorted $\mathrm{PKH} 26^{\text {hi }}$ cells was significantly higher in SKOV3-R tumors $(7.57 \%)$ as compared with that of SKOV3-P cells (2.89\%) ( $\mathrm{P}=0.003)$. Accordingly, the proportion of PKH26 ${ }^{\text {low }}$ cells from SKOV3-R tumors (70.94\%) was significantly higher than that of the SKOV3-P tumors (48.87\%) $(\mathrm{P}=0.002)$, whereas the percentage of $\mathrm{PKH} 26^{\text {neg }}$ cells from SKOV3-R tumors (20.58\%) was significantly lower than that of SKOV3-P tumors $(46.97 \%)(\mathrm{P}=0.002)$. The elevated numbers of PKH26 ${ }^{\text {hi }}$ cells derived from SKOV3-R tumors supported the hypothesis that the administration of cisplatin led to the survival of dormant cells.

Effects of cisplatin on the cell cycle distribution of ovarian cancer cells. Cell cycle control is an important aspect of CSC biology, and deregulated cell cycle control is one of the fundamentally intrinsic steps contributing to CSC-derived tumorigenesis (27). To analyze the differences in the proliferation rate of PKH26-labeled ovarian cancer cells in SKOV3-P and SKOV3-R tumors, the cell cycle distribution of each PKH26 intensity group was evaluated by flow cytometry.

It was demonstrated that $\mathrm{PKH} 26^{\mathrm{hi}}$ cells in the SKOV3-P and SKOV3-R tumors were arrested in the $\mathrm{G}_{0} / \mathrm{G}_{1}$ phase, which further supports the theory that $\mathrm{PKH} 26^{\text {hi }}$ cells represent label-retaining, dormant or slow-cycling cells.

As presented in Fig. 3, PKH26 low cells in SKOV3-P tumors exhibited a slightly higher proportion of cells in the $\mathrm{G}_{0} / \mathrm{G}_{1}$ phase. Of the PKH26 $6^{\text {low }}$ cells in SKOV3-R tumors, the $S$ phase fraction was increased and the $\mathrm{G}_{2} / \mathrm{M}$ phase fraction 

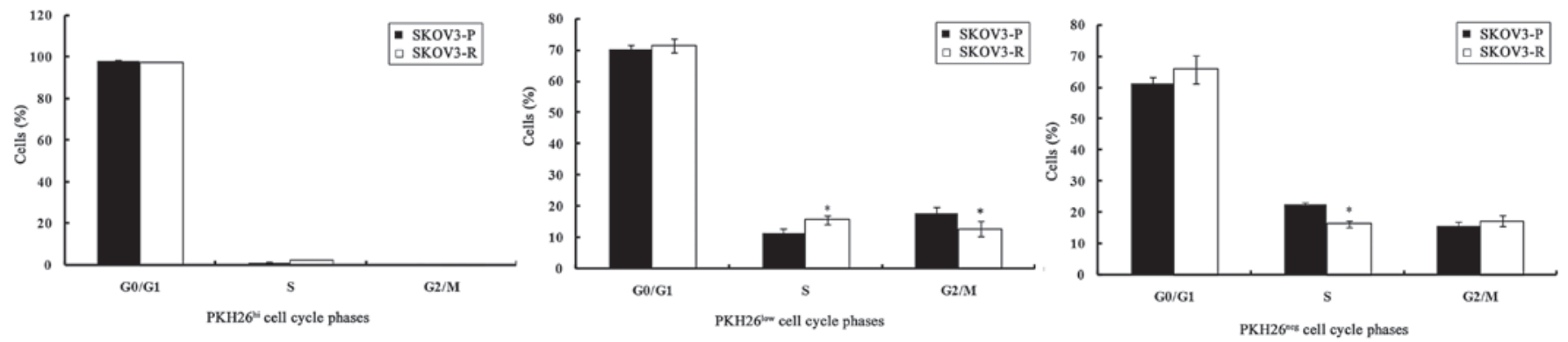

Figure 3. Cell cycle analysis of tumor-derived PKH26 subsets. The graphs represent the percentage of different PKH26 subsets from SKOV3-P and SKOV3-R tumors in the G0/G1, S and G2/M stages of the cell cycle. The data are expressed as the means \pm standard error of the mean. A student's t-test was used to analyze the significance of the results. ${ }^{\text {P }}<0.05$ vs. SKOV3-P tumor group. PKH26 ${ }^{\text {hi }}$, high PKH26 retention, equivalent to pre-injected cells; PKH26 $6^{\text {low }}$, fluorescence intensity lower than pre-injected level; PKH26 ${ }^{\text {neg }}$, total label quenching; SKOV3-P, xenograft control tumors; SKOV3-R xenograft cisplatin treated tumors.
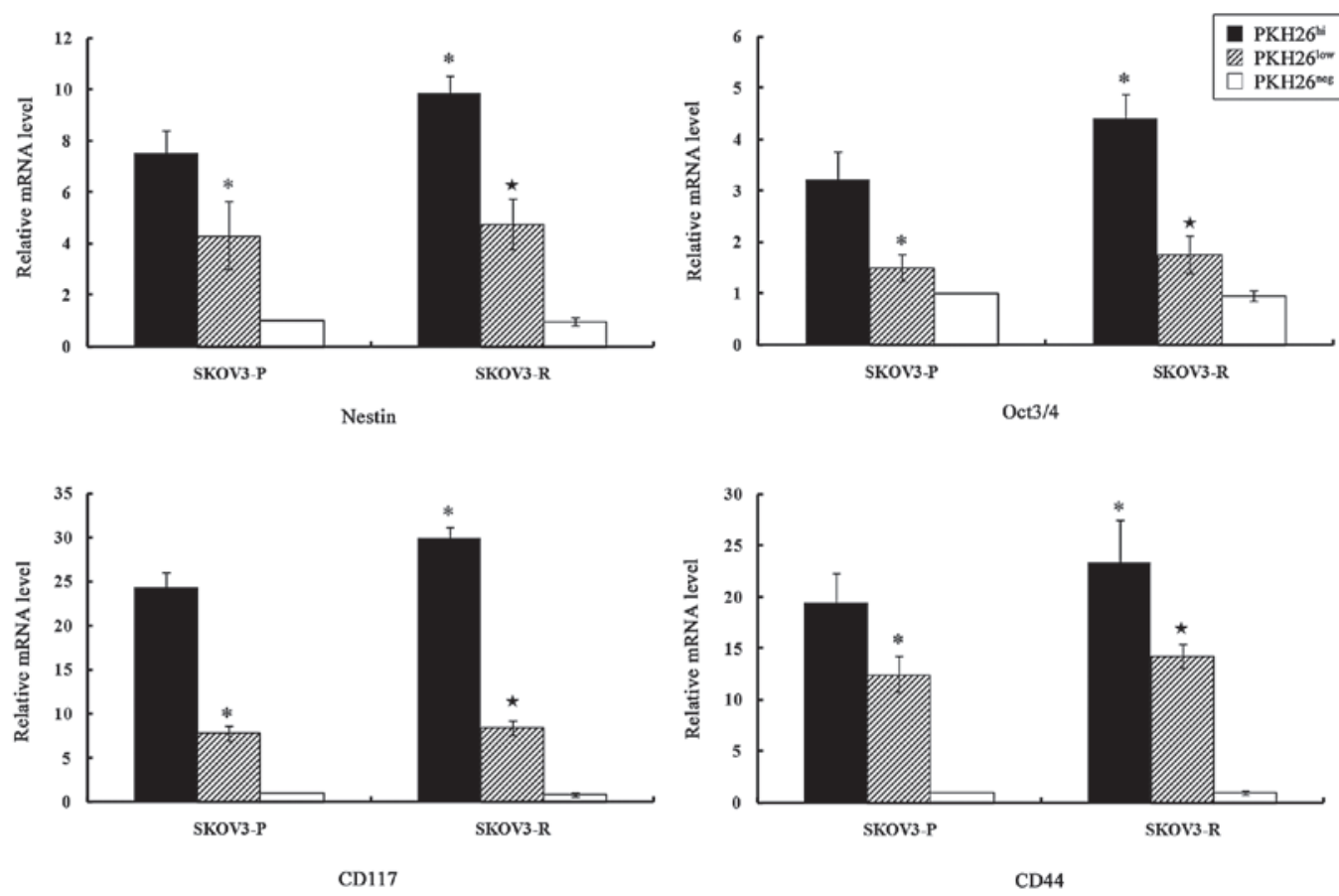

Figure 4. Expression levels of stem cell markers in different subclones from SKOV3-P and SKOV3-R tumors. Total RNA was prepared and the relative gene expression levels were evaluated by quantitative polymerase chain reaction, using GAPDH as an internal control. The bar graphs indicate the relative levels of expression of Nestin, Oct3/4, CD117 and CD44 mRNA in PKH26 $6^{\text {hi }}$, PKH26 $6^{\text {low }}$ and PKH26 ${ }^{\text {neg }}$ subclones from SKOV3-P and SKOV3-R tumors, as determined by relative quantitative analysis using the $2^{-\Delta \mathrm{CCt}}$ method. The data are presented as the means \pm standard error, ${ }^{*} \mathrm{P}<0.05$ vs. SKOV3-P-PKH26 $6^{\mathrm{hi}}$ and ${ }^{\star} \mathrm{P}<0.05$ vs. SKOV3-R-PKH26 $6^{\text {hi }}$. PKH26 $6^{\text {hi, }}$ high PKH26 retention, equivalent to pre-injected cells; PKH26 low , fluorescence intensity lower than pre-injected level; PKH26 $6^{\text {neg }}$, total label quenching; SKOV3-P, xenograft control tumors; SKOV3-R xenograft cisplatin treated tumors.

was reduced significantly $(\mathrm{P}=0.014$ and $\mathrm{P}=0.04$, respectively) as compared with the SKOV3-P tumors. These data suggest that PKH26 $6^{\text {low }}$ cells in SKOV3-R tumors re-enter the cell cycle and develop chemotherapeutic resistance.

PKH26 $6^{\text {neg }}$ populations from SKOV3-P and SKOV3-R tumors were more enriched in the $\mathrm{S}$ phase as compared with the $\mathrm{PKH} 26^{\text {low }}$ population $(\mathrm{P}=0.004$ and $\mathrm{P}=0.001$, respectively), which is in agreement with the characteristics of PKH26 $6^{\text {neg }}$ cells, which exhibited rapid cell division. $\mathrm{PKH} 26^{\text {neg }}$ cells in SKOV3-R tumors displayed an increase in the number of cells in the $\mathrm{G}_{0} / \mathrm{G}_{1}$ and $\mathrm{G}_{2} / \mathrm{M}$ phase and a reduction in the number of cells in the $\mathrm{S}$ phase $(\mathrm{P}=0.2, \mathrm{P}=0.47$ and $\mathrm{P}=0.001$, respectively), as compared with cells from SKOV3-P tumors. Chemotherapy treatment resulted in a non-significant increase $(\mathrm{P}>0.05)$ in the $G_{0} / G_{1}$ and $G_{2} / M$ phase fraction of PKH26 ${ }^{\text {neg }}$ cells from
SKOV3-R tumors in comparison with those in SKOV3-P tumors.

Label-retaining PKH26hi cells preferentially express stem cell markers, which are enhanced by cisplatin. To explore whether PKH26 ${ }^{\text {hi }}$ cells had intrinsic properties conferring stem-like characteristics, the expression of three markers that are important in specific signaling pathways and are crucial in establishing and maintaining stem-like characteristics, were investigated.

qPCR was employed to analyze the expression of stem cell markers in PKH26-labeled ovarian cancer cells from SKOV3-P and SKOV3-R tumors (Fig. 4). PKH26 $6^{\text {hi }}$ cells expressed higher levels of Nestin, Oct3/4, CD117 and CD44 as compared with PKH26 $6^{\text {low }}$ cells $(\mathrm{P}<0.05)$, while $\mathrm{PKH} 26^{\text {neg }}$ cells did not express these stem cell markers. 
Table I. Protein expression of stem cell markers in the three sorted PKH26 cell clones from SKOV3-P and SKOV3-R tumors.

\begin{tabular}{|c|c|c|c|c|}
\hline Cell type & Nestin & Oct $3 / 4$ & CD117 & CD44 \\
\hline SKOV3-P-PKH26 ${ }^{\text {hi }}$ & $102.3 \pm 07.4$ & $65.8 \pm 14.7$ & $277.9 \pm 13.4$ & $191.6 \pm 08.3$ \\
\hline SKOV3-P-PKH26 ${ }^{\text {low }}$ & $18.4 \pm 08.4^{\mathrm{a}}$ & $-16.1 \pm 16.5^{\mathrm{a}}$ & $111.6 \pm 10.4^{\mathrm{a}}$ & $66.2 \pm 05.5^{\mathrm{a}}$ \\
\hline SKOV3-P-PKH26 neg & $-70.2 \pm 34.9^{\mathrm{a}}$ & $-104.4 \pm 30.2^{\mathrm{a}}$ & $-16.3 \pm 16.5^{\mathrm{a}}$ & $-28.5 \pm 26.6^{a}$ \\
\hline SKOV3-R-PKH26 ${ }^{\mathrm{hi}}$ & $142.5 \pm 14.0^{\mathrm{a}}$ & $120.4 \pm 13.3^{\mathrm{a}}$ & $321.1 \pm 09.4^{\mathrm{a}}$ & $228.4 \pm 06.3^{\mathrm{a}}$ \\
\hline SKOV3-R-PKH26 ${ }^{\text {low }}$ & $21.87 \pm 19.8^{\mathrm{b}}$ & $3.8 \pm 21.5^{\mathrm{b}}$ & $127.4 \pm 13.4^{\mathrm{b}}$ & $68.6 \pm 18.6^{\mathrm{b}}$ \\
\hline SKOV3-R-PKH26neg & $-69.23 \pm 28.6^{b}$ & $-129.6 \pm 51.4^{\mathrm{b}}$ & $-5.6 \pm 17.1^{\mathrm{b}}$ & $-18.0 \pm 33.5^{b}$ \\
\hline
\end{tabular}

${ }^{\text {aP }}<0.05$ vs. SKOV3-P-PKH26 ${ }^{\text {hi, }}{ }^{\text {b }} \mathrm{P}<0.05$ vs. SKOV3-R-PKH26 hi. $\mathrm{PKH} 26^{\text {hi, }}$ high PKH26 retention, equivalent to pre-injected cells; $\mathrm{PKH} 26^{\text {low }}$, fluorescence intensity lower than pre-injected level; PKH26 ${ }^{\text {neg }}$, total label quenching; SKOV3-P, xenograft control tumors; SKOV3-R xenograft cisplatin treated tumors.

A
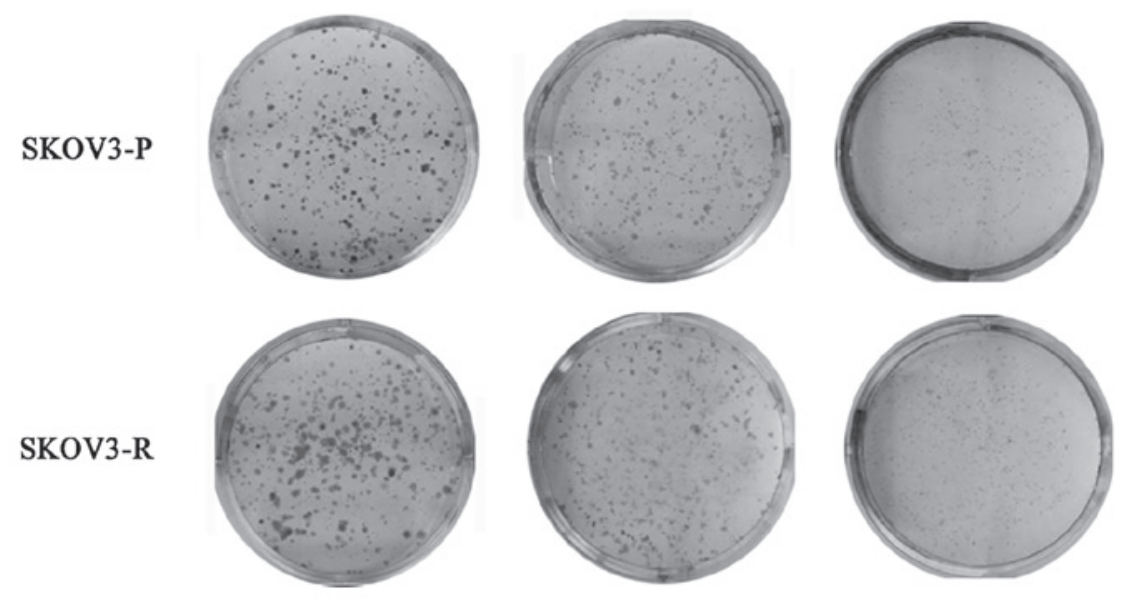

B

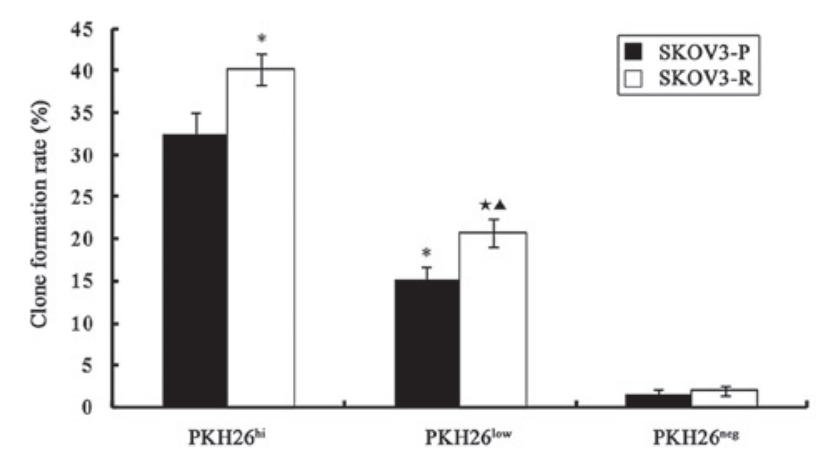

Figure 5. (A) Representative images of the colony forming capabilities of PKH $26^{\text {hi }}, \mathrm{PKH} 26^{\text {low }}$ and PKH26 ${ }^{\text {neg }}$ cells from SKOV3-P and SKOV3-R tumors. (B) The colony formation rate of $\mathrm{PKH} 26^{\text {hi }}, \mathrm{PKH} 26^{\text {low }}$ and $\mathrm{PKH} 26^{\text {neg }}$ cells are expressed as the means \pm standard error. ${ }^{*} \mathrm{P}<0.05$ vs. SKOV3-P-PKH26 $6^{\text {hi }},{ }^{\star} \mathrm{P}<0.05$ vs. SKOV3-R-PKH26 ${ }^{\text {hi }}$ and ${ }^{\boldsymbol{}} \mathrm{P}<0.05$ vs. SKOV3-P-PKH26 ${ }^{\text {low }}$. $\mathrm{PKH}_{2} 6^{\text {hi, }}$ high $\mathrm{PKH} 26$ retention, equivalent to pre-injected cells; $\mathrm{PKH} 26^{\text {low }}$, fluorescence intensity lower than pre-injected level; PKH26 ${ }^{\text {neg }}$, total label quenching. SKOV3-P, xenograft control tumors; SKOV3-R xenograft cisplatin treated tumors.

A significant difference in the expression levels of the stem cell markers existed between SKOV3-P and SKOV3-R PKH26 ${ }^{\mathrm{hi}}$ cells. Nestin, Oct3/4, CD117 and CD44 mRNA were significantly upregulated in $\mathrm{PKH} 26^{\text {hi }}$ cells from SKOV3-R tumors, as compared with SKOV3-P tumors $(\mathrm{P}=0.024, \mathrm{P}=0.045, \mathrm{P}=0.022$ and $\mathrm{P}=0.047$, respectively).

Flow cytometry was used to detect the protein expression levels of stem cell markers in the PKH26-labeled ovarian cancer cells from SKOV3-P and SKOV3-R tumors (Table I). PKH26 ${ }^{\text {hi }}$ cells in SKOV3-P and SKOV3-R tumors expressed significantly higher levels of all four stem cell markers as compared with $\mathrm{PKH} 26^{\text {low }}$ cells $(\mathrm{P}<0.05)$. $\mathrm{PKH} 26^{\text {neg }}$ cells did not express the stem cell markers. PKH26 ${ }^{\text {hi }}$ cells from SKOV3-R tumors expressed significantly higher Nestin, Oct $3 / 4$, CD117 and CD44 protein $(\mathrm{P}=0.04, \mathrm{P}=0.037, \mathrm{P}=0.001$, and $\mathrm{P}=0.04$, respectively), as compared with SKOV3-P-PKH26 ${ }^{\text {hi }}$ cells.

Label-retaining PKH26 ${ }^{\text {hi }}$ cells exhibited colony formation capability and tumorigenicity and cisplatin increased 
Table II. In vivo tumorigenicity of the three screened groups of PKH26 retaining cells from SKOV3-P and SKOV3-R cells.

Tumor formation

\begin{tabular}{lcc} 
Cell type & Cell density & $\mathrm{n}(\%)$ \\
\hline SKOV3-P-PKH26 & & \\
& 10,000 & $3 / 6(50)$ \\
SKOV3-P-PKH26 $^{\text {low }}$ & 10,000 & $5 / 6(83)$ \\
& 20,000 & $0 / 6(0)^{\mathrm{a}}$ \\
SKOV3-P-PKH26 $^{\text {neg }}$ & 10,000 & $0 / 6(0)^{\mathrm{a}}$ \\
& 20,000 & $0 / 6(0)$ \\
SKOV3-R-PKH26 $^{\text {hi }}$ & 10,000 & $0 / 6(0)$ \\
& 20,000 & $5 / 6(83)$ \\
SKOV3-R-PKH26 $^{\text {low }}$ & 10,000 & $6 / 6(100)$ \\
& 20,000 & $0 / 6(0)^{\mathrm{b}}$ \\
SKOV3-R-PKH26 $^{\text {neg }}$ & 10,000 & $2 / 6(33)^{\mathrm{b}}$ \\
& 20,000 & $0 / 6(0)$ \\
\hline
\end{tabular}

All injections were administered subcutaneously. ${ }^{\mathrm{a}} \mathrm{P}<0.05$ vs. SKOV3-P-PKH26 $6{ }^{\text {hi }}{ }^{\mathrm{b}} \mathrm{P}<0.05$ vs. SKOV3-R-PKH $26{ }^{\text {hi }}$. PKH26 ${ }^{\text {hi, }}$ high PKH26 retention, equivalent to pre-injected cells; PKH26 $6^{\text {low }}$, fluorescence intensity lower than pre-injected level; PKH26 ${ }^{\text {neg }}$, total label quenching; SKOV3-P, xenograft control tumors; SKOV3-R xenograft cisplatin treated tumors.

stem-like features. $\mathrm{PKH} 26^{\mathrm{hi}}$ and $\mathrm{PKH} 26^{\text {low }}$ cells demonstrated in vitro clonogenic capability, and the colony formation rate of $\mathrm{PKH} 26^{\text {hi }}$ cells was significantly higher as compared with PKH26 ${ }^{\text {low }}$ cells in SKOV3-P tumors $(\mathrm{t}=11.029, \mathrm{P}=0.001)$ and SKOV3-R tumors $(t=13.81, \mathrm{P}=0.000)$. The colony formation capability was almost absent in $\mathrm{PKH} 26^{\text {neg }}$ cells derived from SKOV3-P and SKOV3-R cells.

As presented in Fig. 5, a significant difference was identified between the clonogenic capability of SKOV3-P and SKOV3-R tumor cells. The rate of colony formation was significantly higher in SKOV-R cells as compared with SKOV3-P cells in $\mathrm{PKH}_{26}{ }^{\text {hi }}(t=4.467, \mathrm{P}=0.011)$ and $\mathrm{PKH} 26^{\text {low }}(t=4.35, \mathrm{P}=0.012)$ cells.

The tumorigenicity of the three groups of screened PKH26-retaining cells from SKOV3-P and SKOV3-R tumors was analyzed in vivo (Table II). The PKH26 ${ }^{\text {hi }}, \mathrm{PKH}_{2} 6^{\text {low }}$ and PKH26 $6^{\text {neg }}$ cells from SKOV3-P and SKOV3-R tumors were transplanted into 5-6-week-old female nude mice at densities of 10,000 or 20,000 cells $/ \mathrm{ml}$.

In SKOV3-P tumors, $\mathrm{PKH} 26^{\text {hi }}$ cells exhibited tumorigenicity at the two cell densities; the tumorigenic rates were $50 \%(3 / 6)$ and $83 \%(5 / 6)$ in the 10,000 and 20,000 cells $/ \mathrm{ml}$ groups, respectively. $\mathrm{PKH} 26^{\text {low }}$ and $\mathrm{PKH} 26^{\text {neg }}$ cells did not exhibit tumorigenicity.

In SKOV3-R tumors, the highly tumorigenic nature of the PKH26 ${ }^{\text {hi }}$ cells was clearly demonstrated at the two cell densities, which were capable of developing tumors. The tumorigenic rates were $83 \%(5 / 6)$ and $100 \%(6 / 6)$ in the 10,000 and 20,000 cells/ml groups, respectively. The minimum cell density of tumor initiation for the $\mathrm{PKH} 26^{\text {hi }}$ cells was 20,000 cells $/ \mathrm{ml}$ and the tumorigenic rate was $33 \%$ (2/6), whereas tumorigenicity was absent in the $\mathrm{PKH} 26^{\text {neg }}$ cells at the two cell densities.
Although there was no statistically significant difference in the tumorigenic rate between SKOV3-P-PKH26 ${ }^{\text {hi }}$ cells and SKOV3-R-PKH26 ${ }^{\text {hi }}$ cells, SKOV3-R-PKH26 ${ }^{\text {hi }}$ cells exhibited slightly higher tumorigenicity. A similar situation was observed in the PKH26 ${ }^{\text {low }}$ cells at a cell density of 20,000 cells $/ \mathrm{ml}(\mathrm{P}>0.05)$.

\section{Discussion}

Tumor dormancy is a stage of tumor progression in which residual disease remains asymptomatic for an extended period of time (28). The presence of dormant tumor cells is an indicator of one of the earliest stages in tumor development, or as minimal residual disease remaining following the successful treatment of the primary tumor by surgical resection and adjuvant treatment (29). Therefore, tumor dormancy is not only a biological property of malignant tumor cells but also a cause of treatment failure, metastasis and recurrence of tumors.

In the current mouse xenograft models, administration of cisplatin led to the inhibition of tumor growth, and xenograft tumors (SKOV3-R tumors) coexisted with their host at a stable size in contrast to the continuously growing SKOV3-P tumors. Additionally, the toxic effects of cisplatin administration in the treatment groups were observed. Although cisplatin induced weight loss, leucopenia, short-time drowsiness, mild skin discoloration and diet decline during the treatment period, the mice exhibited a certain level of tolerance to the chemotherapy. Accordingly, SKOV3-R tumors became drug-resistant following longer periods of cisplatin administration.

Cisplatin is one of the most potent antitumor agents, and has been used clinically for numerous years to treat a wide variety of solid tumors, including head and neck, testicular, ovarian, cervical and lung tumors (30). The cytotoxic mode of action of cisplatin is mediated by its interaction with DNA to form DNA adducts. Platinum-DNA adducts, which are formed following the uptake of cisplatin into the nucleus of cells, activate several cellular processes that mediate the cytotoxicity of chemotherapeutic agents (31). Cisplatin, like many other chemotherapeutic agents, targets rapidly proliferating tumor cells because these cells can absorb more drug into the nucleus, while reduced drug uptake may protect the slow-proliferating tumor cells from chemotherapy. Therefore, it has been predicted that subsequent to intensive and continuous chemotherapy, residual tumor cells may be slow-proliferating cell clones (32).

It is well established that tumors present genetic complexity and heterogeneity; there are multiple subpopulations (also known as subclones) of tumor cells in primary tumors and these subsets have different proliferative capacities and phenotypes (33-36). In the current study, a series of cancer cell clones were successfully isolated from ovarian tumor cells according to PKH26 intensity. These cell clones, $\mathrm{PKH} 26^{\mathrm{hi}}$, PKH26 $6^{\text {low }}$ and PKH26 $6^{\text {neg }}$ cells from SKOV3-P and SKOV3-R tumors, differed in their growth rates and cell cycle distributions, indicating that ovarian cancer cells within xenograft tumors were hierarchically organized, composed of different proliferative subclones. PKH26 $6^{\text {hi }}$ cells existed in SKOV3-P and SKOV3-R tumors and the majority of these cells were arrested in the $G_{0} / G_{1}$ phase. This result further confirmed that $\mathrm{PKH} 26^{\text {hi }}$ cells represent dormant or slow-cycling cells. The findings of the current study indicated that cisplatin 
administration augmented the fraction of PKH26 $6^{\text {hi }}$ cells and reduced the fraction of $\mathrm{PKH} 26^{\text {neg }}$ cells in SKOV3-R tumors, as compared with the proportion of cells in SKOV3-P tumors. The majority of chemotherapeutic agents have the ability to abolish proliferative tumor cells and lead to tumor shrinkage. Thus, drug exposure results in two possibilities: Proliferating cell remission reflects an initial high therapeutic efficacy, or dormant cells may persist within the host as minimal residual disease. It is reasonable that drug exposure should lead to the enrichment of $\mathrm{PKH} 26^{\text {hi }}$ cells, as cells undergoing quiescence or proliferation arrest operate as a safeguard by limiting the extent of DNA damage against chemotherapy.

Thus far, based on stem cell behavior in the normal epithelium, at least four separate criteria have been established for CSCs, including: (i) Self-renewal capacity (37), (ii) the capacity to remain quiescent (38), (iii) resistance to chemotherapy (39) and (iv) enhanced tumorigenicity in mouse models (40). In the present study, the results demonstrated that $\mathrm{PKH} 26^{\text {hi }}$ cells possessed stem-like characteristics. $\mathrm{PKH} 26^{\text {hi }}$ cells proliferated slowly, expressed higher levels of stem cell markers and possessed enhanced clonogenic capability and tumorigenicity as compared with $\mathrm{PKH} 26^{\text {low }}$ and $\mathrm{PKH} 26^{\text {neg }}$ cells. Most notably, the results demonstrated that chemotherapy led to the enrichment of $\mathrm{PKH} 26^{\text {hi }}$ cells, and that $\mathrm{PKH} 26^{\text {hi }}$ cells exhibited significantly higher expression levels of stem cell markers, clonogenic capability and higher tumorigenicity tendencies in SKOV3-R tumors as compared with those in SKOV3-P tumors. CSCs in primary tumors may avoid the first round of chemotherapy and/or radiotherapy and gradually lead to tumor recurrence. The current study indicated that cisplatin altered the proportion and stemness of dormant stem-like SKOV3 PKH26 ${ }^{\text {hi }}$ cell clones. Cancer cells are organized hierarchically within tumors and not all cells are equal (38). Chemotherapy and/or radiotherapy may alter this hierarchy. In the present study, SKOV3-R-PKH26 ${ }^{\text {hi }}$ cells with enhanced stem-like features suggested that chemotherapy may activate this pathway of subclone transition. In the clinical practice, intensive and continuous chemotherapy is also attributed to increased chemoresistance and the formation of aggressive cancer cell clones in patients. A novel challenge is the maintenance of the equilibrium between longer high-quality survival and the optimal chemotherapy model. This new optimal chemotherapy model should kill sensitive cancer cells and enable patients to be asymptomatic, and would allow sensitive cancer cells to be the dominant clone in residual tumor cell clones.

In conclusion, the present study identified that there were multiple cell clones (PKH26 ${ }^{\text {hi }}, \mathrm{PKH} 26^{\text {low }}$ and PKH26 ${ }^{\text {neg }}$ cells) in single cell line-generated xenograft tumors, and these cell clones exhibited various growth rates, cell cycle distributions and expression profiles of stem cell markers. PKH26 $6^{\text {hi }}$ cells were dormant or slow-cycling cells and exhibited stem-like properties. To the best of our knowledge, the findings of the present study are the first to demonstrate that chemotherapy leads to the enrichment of $\mathrm{PKH} 26^{\text {hi }}$ cell clones, and seemly enhances the stemness of SKOV3-R-PKH26 ${ }^{\text {hi }}$ cells. These dormant or slow-cycling cell clones bearing stem cell properties may facilitate the adaptation of cells to the foreign microenvironment and eventually lead to drug resistance. Future studies are required to explore the effects of different chemotherapeutic models on the equilibrium between maintaining the chemotherapeutic sensitivity of residual tumor cells and providing a longer survival and higher quality of life for patients.

\section{Acknowledgements}

The present study was supported by the Natural Science Foundation of Hebei Province, China (no. c2010002011).

\section{References}

1. Cannistra SA: Cancer of the ovary. N Engl J Med 351: 2519-2529, 2004.

2. Levanon K, Crum C and Drapkin R: New insights into the pathogenesis of serous ovarian cancer and its clinical impact. J Clin Oncol 26: 5284-5293, 2008

3. Thigpen JT, Aghajanian CA, Alberts DS, et al: Role of pegylated liposomal doxorubicin in ovarian cancer. Gynecol Oncol 96: $10-18,2005$.

4. Aguirre-Ghiso JA: Models, mechanisms and clinical evidence for cancer dormancy. Nat Rev Cancer 7: 834-846, 2007.

5. Bhattacharyya S and Khanduja KL: New hope in the horizon: cancer stems cells. Acta Biochim Biophys Sin (Shanghai) 42: 237-242, 2010.

6. Pelayo R, Miyazaki K, Huang J, et al: Cell cycle quiescence of early lymphoid progenitors in adult bone marrow. Stem Cells 24: 2703-2713, 2006.

7. Yahata T, Muguruma Y, Yumino S, et al: Quiescent human hematopoietic stem cells in the bone marrow niches organize the hierarchical structure of hematopoiesis. Stem Cells 26: 3228-3236, 2008.

8. Visvader JE and Lindeman GJ: Cancer stem cells in solid tumours: accumulating evidence and unresolved questions. Nat Rev Cancer 8: 755-768, 2008

9. Morel AP, Lièvre M, Thomas C, et al: Generation of breast cancer stem cells through epithelial-mesenchymal transition. PLoS One 3: e2888, 2008 .

10. Hellsten R, Johansson M, Dahlman A, Sterner O and Bjartell A: Galiellalactone inhibits stem cell-like ALDH-positive prostate cancer cells. PLoS One 6: e22118, 2011.

11. Belton A, Gabrovsky A, Bae YK, et al: HMGA1 induces intestinal polyposis in transgenic mice and drives tumor progression and stem cell properties in colon cancer cells. PLoS One 7: e30034, 2012.

12. Rosen JM and Jordan CT: The increasing complexity of the cancer stem cell paradigm. Science 324: 1670-1673, 2009.

13. Dubeau L: The cell of origin of ovarian epithelial tumours. Lancet Oncol 9: 1191-1197, 2008.

14. Bapat SA: Human ovarian cancer stem cells. Reproduction 140: 33-41, 2010.

15. Lendahl U, Zimmerman LB and McKay RD: CNS stem cells express a new class of intermediate filament protein. Cell 60: 585-595, 1990.

16. Ishiwata T, Matsuda $Y$ and Naito Z: Nestin in gastrointestinal and other cancers: effects on cells and tumor angiogenesis. World J Gastroenterol 17: 409-418, 2011.

17. de Jong J and Looijenga LH: Stem cell marker OCT3/4 in tumor biology and germ cell tumor diagnostics: history and future. Crit Rev Oncog 12: 171-203, 2006.

18. Hombach-Klonisch S, Paranjothy T, Wiechec E, et al: Cancer stem cells as targets for cancer therapy: selected cancers as examples. Arch Immunol Ther Exp (Warsz) 56: 165-180, 2008.

19. Bapat SA, Mali AM, Koppikar CB and Kurrey NK: Stem and progenitor-like cells contribute to the aggressive behavior of human epithelial ovarian cancer. Cancer Res 65: 3025-3029, 2005.

20. Sayed SI, Dwivedi RC, Katna R, et al: Implications of understanding cancer stem cell (CSC) biology in head and neck squamous cell cancer. Oral Oncol 47: 237-243, 2011.

21. Yasui W, Sentani K, Sakamoto N, et al: Molecular pathology of gastric cancer: research and practice. Pathol Res Pract 207: 608-612, 2011.

22. Matsuda Y, Kure S and Ishiwata T: Nestin and other putative cancer stem cell markers in pancreatic cancer. Med Mol Morphol 45: 59-65, 2012. 
23. Ma L, Lai D, Liu T, et al: Cancer stem-like cells can be isolated with drug selection in human ovarian cancer cell line SKOV3. Acta Biochim Biophys Sin (Shanghai) 42: 593-602, 2010.

24. Reber L, Da Silva CA and Frossard N: Stem cell factor and its receptor c-Kit as targets for inflammatory diseases. Eur J Pharmacol 533: 327-340, 2006.

25. Yue Z, Jiang TX, Widelitz RB and Chuong CM: Mapping stem cell activities in the feather follicle. Nature 438: 1026-1029,2005.

26. Martin-Padura I, Marighetti P, Agliano A, et al: Residual dormant cancer stem-cell foci are responsible for tumor relapse after antiangiogenic metronomic therapy in hepatocellular carcinoma xenografts. Lab Invest 92: 952-966, 2012.

27. Gao MQ, Choi YP, Kang S, Youn JH and Cho NH: CD24+ cells from hierarchically organized ovarian cancer are enriched in cancer stem cells. Oncogene 29: 2672-2680, 2010.

28. Patel P and Chen EI: Cancer stem cells, tumor dormancy, and metastasis. Front Endocrinol (Lausanne) 3: 125, 2012.

29. Páez D, Labonte MJ, Bohanes P, et al: Cancer dormancy: a model of early dissemination and late cancer recurrence. Clin Cancer Res 18: 645-653, 2012.

30. Rabik CA and Dolan ME: Molecular mechanisms of resistance and toxicity associated with platinating agents. Cancer Treat Rev 33: 9-23, 2007.

31. Martin LP, Hamition TC and Schilder RJ: Platinum resistance: the role of DNA repair pathways. Clin Cancer Res 14: 1291-1295, 2008
32. Kusumbe AP and Bapat SA: Cancer stem cells and aneuploid populations within developing tumors are the major determinants of tumor dormancy. Cancer Res 69: 9245-9253, 2009.

33. Fleuren GJ, Gorter A, Kuppen PJ, Litvinov S and Warnaar SO: Tumor heterogeneity and immunotherapy of cancer. Immunol Rev 145: 91-122, 1995.

34. Reya T, Morrison SJ, Clarke MF and Weissman IL: Stem cells, cancer, and cancer stem cells. Nature 414: 105-111, 2001.

35. Yaqui-Beltrán A, He B and Jablons DM: The role of cancer stem cells in neoplasia of the lung: past, present and future. Clin Transl Oncol 10: 719-725, 2008.

36. Shackleton M: Normal stem cells and cancer stem cells: similar and different. Semin Cancer Biol 20: 85-92, 2010.

37. Dalerba P, Cho RW and Clarke MF: Cancer stem cells: models and concepts. Annu Rev Med 58: 267-284, 2007.

38. Friel AM, Sergent PA, Patnaude C, et al: Functional analyses of the cancer stem cell-like properties of human endometrial tumor initiating cells. Cell Cycle 7: 242-249, 2008.

39. Hermann PC, Huber SL, Herrler T, et al: Distinct populations of cancer stem cells determine tumor growth and metastatic activity in human pancreatic cancer. Cell Stem Cell 1: 313-323, 2007.

40. Li C, Heidt DG, Dalerba P, et al: Identification of pancreatic cancer stem cells. Cancer Res 67: 1030-1037, 2007.

41. Gilbertson RJ and Graham TA: Cancer: Resolving the stem-cell debate. Nature 488: 462-463, 2012. 